\title{
A Cross-sectional Epidemiological Survey on Prevalence of Malocclusion in Government, Aided and Private School Children of Karnataka
}

\author{
Roopa Siddegowda ${ }^{*}$, Rani. M.S \\ Vokkaligara Sangha Dental College \& Hospital, Rajiv Gandhi University of Health Sciences, Bangalore 560004, Karnataka, India \\ *Corresponding Author: roopagowda@ymail.com
}

Copyright (C) 2013 Horizon Research Publishing All rights reserved.

\begin{abstract}
Many population surveys have been carried out in different parts of the world with the objective of estimating prevalence of malocclusion and orthodontic treatment needs. Malocclusion is still considered a dental problem in developing country like India and often neglected because more priority is given to the problems of dental caries and periodontal diseases. Most malocclusion cases are still not treated properly because due to ignorance of patients and parents, inadequacy of dental resources, lack of dental workforce and many of the other factors that have influenced the availability of services. This survey was formulated to investigate the same and to provide strategies for prevention, corrective treatment and to create awareness of orthodontic treatment.
\end{abstract}

Keywords Prevalence, Malocclusion, Government School, Aided School, Private School, Karnataka India

\section{Introduction}

Malocclusion is one of the most common dental problem in mankind, together with dental caries, gingival disease, and dental fluorosis [1]. Mal-occluded teeth can cause psychosocial problems related to impaired dento-facial aesthetics [2], disturbances of oral function such as mastication, swallowing and speech [3] and greater susceptibility to periodontal disease $[4,5]$. Malocclusion is not a single entity but rather a collection of situations each in itself constituting a problem; many of the situations are complicated by a multiplicity of causes and are reversible through growth and development or through tooth loss and treatment [6]. Interest to orthodontic treatment has increased in recent years, as a consequence of patients' expectations as regards to oral impact on quality of life and treatment opportunities. Moreover, the importance of oral health related quality of life is particularly relevant for children and adolescents, since younger subjects are more sensitive to a variety of impacts, such as appearance, that may affect their current quality of life and psychological development and ultimately result in influencing their social skills and education. Chen and Hunter [7] found that psychological impacts of oral health, such as avoiding laughing and being teased about teeth, were more prevalent in children than in adults and elderly. In every country, there is a need to identify different malocclusions, their incidence, and the need for treatment so that appropriate manpower arrangement can be made. In this context, the objective of the present epidemiological study was to determine the prevalence of malocclusion in school children of Government, Aided and Private schools in Karnataka, India.

\section{Materials and Methods}

Karnataka is a vast state in India constituting 30 districts. The state covers an area of 191,976 square kilometres $(74,122 \mathrm{sq} \mathrm{mi})$, or $5.83 \%$ of the total geographical area of India. A cross-sectional epidemiological survey was conducted in the State of Karnataka, by obtaining prior permission from the Ministry of Higher Primary and Secondary Education Board of Karnataka. The survey was carried out in selected schools in all the district head quarters. Children in the age group of 10-16 years were included in the study and constituted the study population. Population proportionate technique was employed for sample size estimation. According to the population census 2011, the total population in Karnataka was 61130704 out of which 10-16 years old children constitute 29\% (According to National Family Health Survey-2, India [1998-99], child population in the age group of 10-16 years was taken as a reference). With $95 \%$ confidence level, the estimated sample size was 9505 . In the first stage of sampling, three categories of schools, namely, Government schools, Aided schools, and Private schools in each district were selected from a list of schools provided by the Karnataka Higher Primary and Secondary Education Board by simple randomization method. In the second stage, 102 schools all over Karnataka 
were surveyed during the year 2012-2013. A total sample of 9505 children in the age group of 10-16 years was included from the randomized schools in each district all over Karnataka. Children who obtained written informed consent from parents to participate in the study were included. Exclusion criteria used were- history of previous orthodontic treatment, rampant caries, multiple missing teeth, mutilated malocclusion and other craniofacial anomalies like cleft lip and palate, facial hemiatropy, cleidocranial dysplasia etc.

Ethical clearance to conduct the survey was obtained from the Vokkaligara Sangha Dental College and Hospital Review and Ethical Committee. Prior permission to conduct the survey was taken from the concerned school authorities.

The oral examination was done in day light using mouth mirror and dental probe. The observations were recorded in the assessment form and later transferred to the PC. Few modifications were done to Ackermann-Proffit [8] classification of malocclusion which was used to record the malocclusion. The Dental Health check-up was done for the remaining children and an oral health education lecture was given to all the children in the school to create awareness about Dental health and Orthodontic treatment.

\subsection{Karnataka State Map}

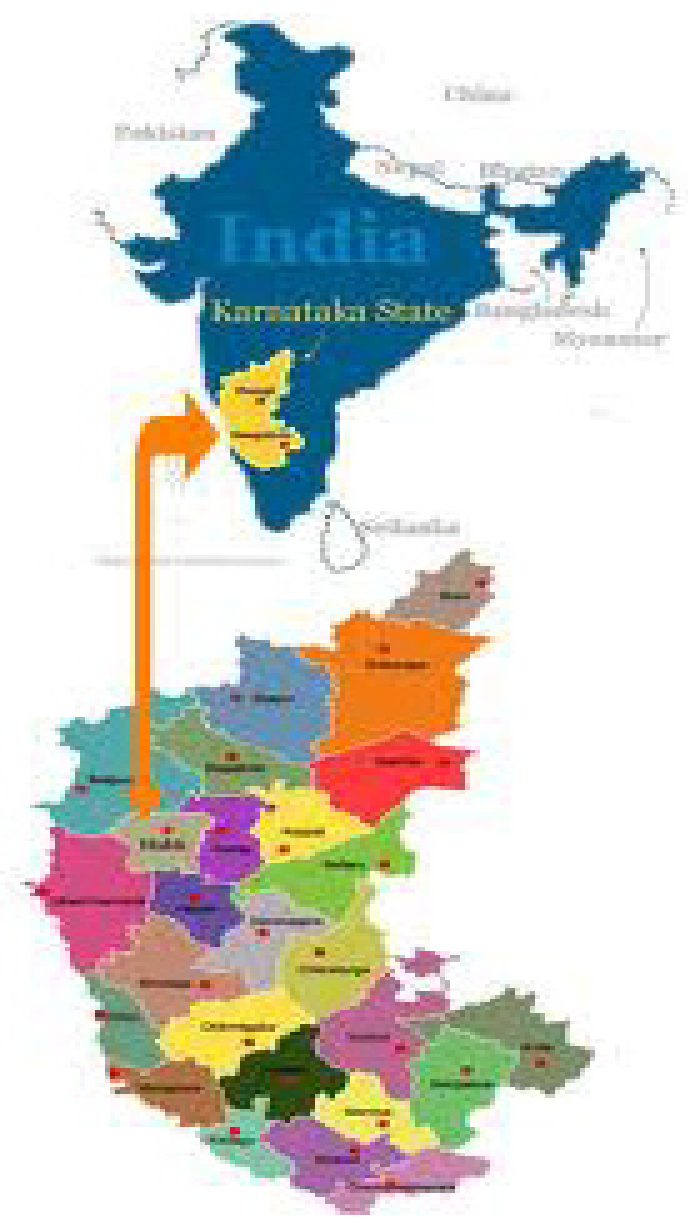

\subsection{Ackermann-Proffit System of Classification of Malocclusion [Modified Version] to Record the Malocclusion.}

This includes 6 categories like Alignment, Skeletal deviations, Transverse deviations, Antero-posterior deviations, Vertical deviations and Oral habits.

The description of the criterias in each of these categories are as follows:

1. Alignment-

i. Midline ---

0 -Midlines coinciding,

$1-<$ half the lower incisor width,

2- $\quad>$ half the lower incisor width.

ii. Spacing---

0 - Absent,

1- Midline diastema,

2- Anterior spacing,

3- Generalized spacing

iii. Crowding---

0- Absent,

1- Anterior crowding [a] Mild ,[b] Moderate, [c] Severe,

2- Posterior crowding

iv. Protrusion of teeth---

0 - Absent

1- Protrusion of upper teeth,

2- Protrusion of lower teeth,

3- Protrusion of both upper and lower teeth

v. Retrusion of teeth---

Absent

1-Retrusion of upper teeth,

2- Retrusion of lower teeth,

3- Retrusion of both upper and lower teeth.

2. Skeletal deviations -

i. Profile---

1-Straight profile,

2-Anterior divergent,

3-Posterior divergent,

4-Convex profile,

5-Concave profile

ii. Maxillary position---

0-Normal maxilla,

1-Prognathic maxilla,

2-Retrognathic maxilla

iii. Mandibular position---

0 -Normal mandible,

1-Prognathic mandible,

2-Retrognathic mandible.

3. Transverse deviation-

i. Crossbite---

0 -No crossbite,

1-Single tooth crossbite,

2-Two or more teeth crossbite,

3-Anterior teeth crossbite, 
4-Posterior Unilateral crossbite,

5-Posterior Bilateral crossbite.

4. Anteroposterior deviations-

i. Molar relation---

1-Class I,

2-Class II [a] div1 [b] div2 [c]subdivision,

3-Class III [a]sub division.

ii. Overjet---

1-Normal overjet[1-3mm],

2-Moderate overjet[3-5mm],

3 -Increased overjet [ $>6 \mathrm{~mm}]$,

4-Reduced overjet $[<1 \mathrm{~mm}]$,

5- Reverse overjet.

\section{Vertical deviations-}

i. Overbite---

$1-1 / 3^{\text {rd }}$ of lower incisor overlap,

$2-2 / 3^{\text {rd }}$ of lower incisor overlap,

3-Completely locked lower incisors,

4-Edge to edge bite.

ii. Openbite--- 0-Openbite absent ,

1-Open bite $<2 \mathrm{~mm}$,

2- Open bite $>4 \mathrm{~mm}$.
0 -Absent

1 -Thumb sucking

2-Tongue thrusting

3-Lip biting

4-Nail biting

5-Mouth breathing.

\section{Result}

\section{Statistical analysis}

Data were coded and entered into excel sheet. To maintain the data quality (validity) rechecking and cross checking were done during data entry phase. Later, data were transformed into SPSS windows version 16, where coding, recording, crosschecking, processing and analysis of data were done.

Simple descriptive statistics were used to describe the study variables. One-way Anova and Cross-tabulations were applied. The frequency and the distribution of each variant of malocclusion between the Government, Aided and

6. Oral habits-

Table 1. Prevalence of midline deviation

\begin{tabular}{|c|c|c|c|c|c|}
\hline \multirow{2}{*}{$\begin{array}{c}\text { SCHOOL } \\
\text { TYPE }\end{array}$} & & \multicolumn{3}{|c|}{ MIDLINE } & \multirow{2}{*}{ Total } \\
\cline { 3 - 5 } & Co-inciding & $\begin{array}{c}<1 / 2 \text { Lower Incisor } \\
\text { width }\end{array}$ & $\begin{array}{c}>1 / 2 \text { Lower } \\
\text { Incisor width }\end{array}$ & \\
\hline Government & F\&\% & $2068(65.9 \%)$ & $880(28.0 \%)$ & $191(6.1 \%)$ & $3139(100.0 \%)$ \\
\hline Aided & F\&\% & $2130(65.8 \%)$ & $893(27.6 \%)$ & $215(6.6 \%)$ & $3238(100.0 \%)$ \\
\hline Private & F\&\% & $2140(68.4 \%)$ & $764(24.4 \%)$ & $22(47.2 \%)$ & $3128(100.0 \%)$ \\
\hline Total & F\&\% & $6338(66.7 \%)$ & $2537(26.7 \%)$ & $630(6.6 \%)$ & $9505(100.0 \%)$ \\
\hline
\end{tabular}

Contingency Coefficient $=.038 ; \mathrm{P}=.007$

Table 2. Prevalence of spacing discrepancy

\begin{tabular}{|c|c|c|c|c|c|c|}
\hline \multirow{2}{*}{$\begin{array}{c}\text { SCHOOL } \\
\text { TYPE }\end{array}$} & & \multicolumn{4}{|c|}{ SPACING } & \multirow{2}{*}{ Total } \\
\cline { 3 - 6 } & Absent & Diastema & Anterior spacing & $\begin{array}{c}\text { Generalized } \\
\text { spacing }\end{array}$ & \\
\hline Government & F\&\% & $2662(84.8 \%)$ & $199(6.3 \%)$ & $248(7.9 \%)$ & $30(1.0 \%)$ & $3139(100.0 \%)$ \\
\hline Aided & F\&\% & $2770(85.5 \%)$ & $199(6.1 \%)$ & $245(7.6 \%)$ & $24(.7 \%)$ & $3238(100.0 \%)$ \\
\hline Private & F\&\% & $2675(85.5 \%)$ & $189(6.0 \%)$ & $233(7.4 \%)$ & $31(1.0 \%)$ & $3128(100.0 \%)$ \\
\hline Total & F\&\% & $8107(85.3 \%)$ & $587(6.2 \%)$ & $726(7.6 \%)$ & $85(.9 \%)$ & $9505(100.0 \%)$ \\
\hline
\end{tabular}

Contingency Coefficient $=.015 ; \mathrm{P}=.908$

Table 3. Prevalence of crowding

\begin{tabular}{|c|c|c|c|c|c|c|c|}
\hline \multirow{2}{*}{$\begin{array}{c}\text { SCHOOL } \\
\text { TYPE }\end{array}$} & & \multicolumn{5}{|c|}{ CROWDING } & \multirow{2}{*}{ Total } \\
\cline { 3 - 7 } & & Absent & Mild & Moderate & Severe & Posterior & \\
\hline Government & F\&\% & $1592(50.7 \%)$ & $674(21.5 \%)$ & $487(15.5 \%)$ & $193(6.1 \%)$ & $193(6.1 \%)$ & $3139(100.0 \%)$ \\
\hline Aided & F\&\% & $1581(48.8 \%)$ & $603(18.6 \%)$ & $543(16.8 \%)$ & $256(7.9 \%)$ & $255(7.9 \%)$ & $3238(100.0 \%)$ \\
\hline Private & F\&\% & $1495(47.8 \%)$ & $606(19.4 \%)$ & $578(18.5 \%)$ & $253(8.1 \%)$ & $196(6.3 \%)$ & $3128(100.0 \%)$ \\
\hline Count & F\&\% & $4668(49.1 \%)$ & $1883(16.9 \%)$ & $1608(16.9 \%)$ & $702(7.4 \%)$ & $644(6.8 \%)$ & $9505(100.0 \%)$ \\
\hline
\end{tabular}

Contingency Coefficient $=.062 ; \mathrm{P}=.000(\mathrm{HS})$ 
Table 4. Prevalence of protrusion of teeth

\begin{tabular}{|c|c|c|c|c|c|c|}
\hline \multirow{2}{*}{$\begin{array}{c}\text { SCHOOL } \\
\text { TYPE }\end{array}$} & & \multicolumn{4}{|c|}{ PROTRUSION } & \multirow{2}{*}{ Total } \\
\cline { 3 - 6 } & & Absent & Upper teeth & Lower teeth & Both & \\
\hline Government & F\&\% & $1618(51.5 \%)$ & $883(28.1 \%)$ & $10(.3 \%)$ & $628(20.0 \%)$ & $3139(100.0 \%)$ \\
\hline Aided & F\&\% & $1701(52.5 \%)$ & $877(27.1 \%)$ & $20(.6 \%)$ & $640(19.8 \%)$ & $3238(100.0 \%)$ \\
\hline Private & F\&\% & $1616(51.7 \%)$ & $889(28.4 \%)$ & $15(.5 \%)$ & $608(19.4 \%)$ & $3128(100.0 \%)$ \\
\hline Count & F\&\% & $4935(51.9 \%)$ & $2649(27.9 \%)$ & $45(.5 \%)$ & $1876(19.7 \%)$ & $9505(100.0 \%)$ \\
\hline
\end{tabular}

Contingency Coefficient $=.022 ; \mathrm{P}=.574$

Table 5. Prevalence of retrusion of teeth

\begin{tabular}{|c|c|c|c|c|c|c|}
\hline \multirow{2}{*}{$\begin{array}{c}\text { SCHOOL } \\
\text { TYPE }\end{array}$} & & \multicolumn{4}{|c|}{ RETRUSION } & \multirow{2}{*}{ Total } \\
\cline { 3 - 6 } & & Absent & Upper teeth & Lower teeth & Both & \multirow{2}{*}{$3139(100.0 \%)$} \\
\hline Government & $\mathrm{F} \& \%$ & $2772(88.3 \%)$ & $321(10.2 \%)$ & $18(.6 \%)$ & $28(.9 \%)$ & $3238(100.0 \%)$ \\
\hline Aided & $\mathrm{F} \& \%$ & $2856(88.2 \%)$ & $357(11.0 \%)$ & $5(.2 \%)$ & $20(.6 \%)$ & $3128(100.0 \%)$ \\
\hline Private & $\mathrm{F} \& \%$ & $2769(88.5 \%)$ & $336(10.7 \%)$ & $7(.2 \%)$ & $16(.5 \%)$ & $305(100.0 \%)$ \\
\hline Total & $\mathrm{F} \& \%$ & $8397(88.3 \%)$ & $1014(10.7 \%)$ & $30(.3 \%)$ & $64(.7 \%)$ & $9505(\%)$ \\
\hline
\end{tabular}

Contingency Coefficient $=.039 ; \mathrm{P}=.023$

Table 6. Prevalence of profile

\begin{tabular}{|c|c|c|c|c|c|c|c|}
\hline \multirow{2}{*}{\begin{tabular}{c}
\multirow{2}{*}{$\begin{array}{c}\text { SCHOOL } \\
\text { TYPE }\end{array}$} \\
\cline { 3 - 7 }
\end{tabular}} & & \multicolumn{5}{|c|}{ PROFILE } & \multirow{2}{*}{ Total } \\
\hline Government & $\mathrm{F} \& \%$ & $1040(33.1 \%)$ & $2(.1 \%)$ & $2(.1 \%)$ & $2082(66.3 \%)$ & $13(.4 \%)$ & $3139(100.0 \%)$ \\
\hline Aided & $\mathrm{F} \& \%$ & $1042(32.2 \%)$ & $1(.0 \%)$ & $0(.0 \%)$ & $2177(67.2 \%)$ & $18(.6 \%)$ & $3238(100.0 \%)$ \\
\hline Private & $\mathrm{F} \& \%$ & $1007(32.2 \%)$ & $1(.0 \%)$ & $0(.0 \%)$ & $2099(67.1 \%)$ & $21(.7 \%)$ & $3128(100.0 \%)$ \\
\hline Total & $\mathrm{F} \& \%$ & $3089(32.5 \%)$ & $4(.0 \%)$ & $2(.0 \%)$ & $6358(66.9 \%)$ & $52(.5 \%)$ & $9505(100.0 \%)$ \\
\hline
\end{tabular}

Contingency Coefficient $=.028 ; \mathrm{P}=.506$

Table 7. Prevalence of cross-bite

\begin{tabular}{|c|c|c|c|c|c|c|c|c|}
\hline \multirow{2}{*}{$\begin{array}{c}\text { SCHOOL } \\
\text { TYPE }\end{array}$} & & \multicolumn{6}{|c|}{ CROSSBITE } & \multirow{2}{*}{ Total } \\
\hline & & Absent & Single tooth & $\begin{array}{c}\text { Two or more } \\
\text { teeth }\end{array}$ & $\begin{array}{c}\text { Anterior } \\
\text { teeth }\end{array}$ & $\begin{array}{l}\text { Posterior } \\
\text { unilateral }\end{array}$ & $\begin{array}{r}\text { Posterior } \\
\text { bilateral }\end{array}$ & \\
\hline Government & $F \& \%$ & $2627(83.7 \%)$ & $356(11.3 \%)$ & $90(2.9 \%)$ & $37(1.2 \%)$ & $20(.6 \%)$ & $9(.3 \%)$ & $3139(100.0 \%)$ \\
\hline Aided & $\mathrm{F} \& \%$ & $2652(81.9 \%)$ & $413(12.8 \%)$ & $104(3.2 \%)$ & $333(1.0 \%)$ & $29(.9 \%)$ & $7(.2 \%)$ & $3238(100.0 \%)$ \\
\hline Private & $\mathrm{F} \& \%$ & $2518(80.5 \%)$ & $404(12.9 \%)$ & $127(4.1 \%)$ & $47(1.5 \%)$ & $22(.7 \%)$ & $10(.3 \%)$ & $3128(100.0 \%)$ \\
\hline Total & $\mathrm{F} \& \%$ & $7797(82.0 \%)$ & $1173(12.3 \%)$ & $321(3.4 \%)$ & $117(1.2 \%)$ & $71(.7 \%)$ & $26(.3 \%)$ & $9505(100.0 \%)$ \\
\hline
\end{tabular}

Contingency Coefficient $=.044 ; \mathrm{P}=.053$

Table 8. Prevalence of molar-relation

\begin{tabular}{|c|c|c|c|c|c|c|c|}
\hline \multirow{2}{*}{$\begin{array}{c}\text { SCHOOL } \\
\text { TYPE }\end{array}$} & & \multicolumn{5}{|c|}{ ANGLE'S MOLAR RELATION } & \multirow{2}{*}{ Total } \\
\cline { 3 - 7 } & & ClassI & $\begin{array}{c}\text { ClassII } \\
\text { Division1 }\end{array}$ & $\begin{array}{c}\text { ClassII } \\
\text { Division2 }\end{array}$ & $\begin{array}{c}\text { ClassII } \\
\text { Subdivision }\end{array}$ & ClassIII & \\
\hline Government & F\&\% & $2482(79.1 \%)$ & $449(14.3 \%)$ & $117(3.7 \%)$ & $91(2.9 \%)$ & $0(.0 \%)$ & $3139(100.0 \%)$ \\
\hline Aided & F\&\% & $2586(79.9 \%)$ & $408(12.6 \%)$ & $119(3.7 \%)$ & $124(3.8 \%)$ & $1(.0 \%)$ & $3238(100.0 \%)$ \\
\hline Private & F\&\% & $2462(78.7 \%)$ & $407(13.0 \%)$ & $139(4.4 \%)$ & $116(3.7 \%)$ & $4(.1 \%)$ & $3128(100.0 \%)$ \\
\hline Total & F\& $\%$ & $7530(79.2 \%)$ & $1264(13.3 \%)$ & $375(3.9 \%)$ & $331(3.5 \%)$ & $5(.1 \%)$ & $9505(100.0 \%)$ \\
\hline
\end{tabular}

Contingency Coefficient $=.042 ; \mathrm{P}=.031$ 
Table 9. Prevalence of overjet

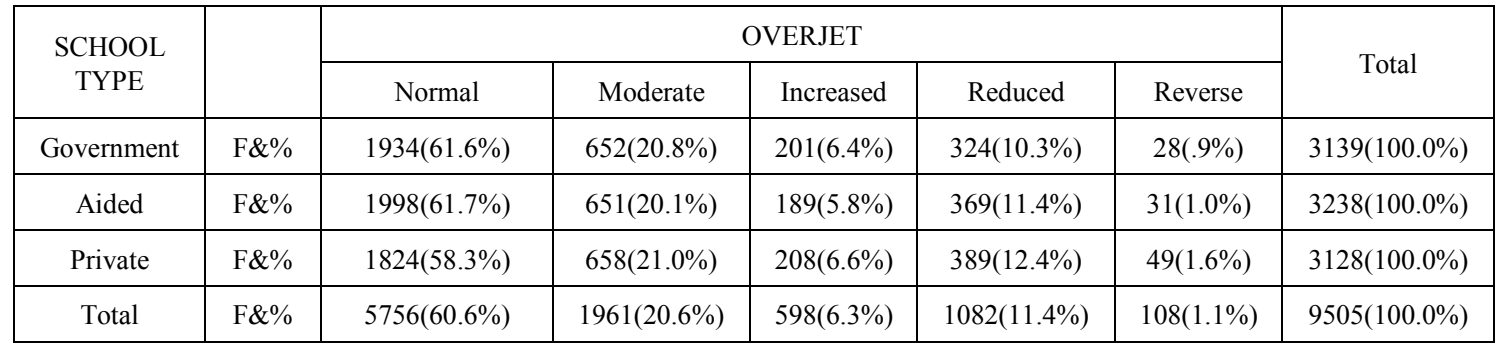

Contingency Coefficient $=.046 ; \mathrm{P}=.010$

Table 10. Prevalence of overbite

\begin{tabular}{|c|c|c|c|c|c|c|}
\hline \multirow{2}{*}{$\begin{array}{l}\text { SCHOOL } \\
\text { TYPE }\end{array}$} & & \multicolumn{4}{|c|}{ OVERBITE } & \multirow{2}{*}{ Total } \\
\hline & & $\begin{array}{c}\text { Overlapping } \\
1 / 3 \text { the Lower Incisor }\end{array}$ & $\begin{array}{c}\text { Overlapping } \\
2 / 3 \text { the Lower Incisor }\end{array}$ & Complete overlap & Edge to Edge & \\
\hline Government & $F \& \%$ & $1235(39.3 \%)$ & $1243(39.6 \%)$ & $433(13.8 \%)$ & $228(7.3 \%)$ & $3139(100.0 \%)$ \\
\hline Aided & $\mathrm{F} \& \%$ & $1182(36.5 \%)$ & $1321(40.8 \%)$ & $506(15.6 \%)$ & $229(7.1 \%)$ & $3238(100.0 \%)$ \\
\hline Private & $F \& \%$ & $1085(34.7 \%)$ & $1376(44.0 \%)$ & $483(15.4 \%)$ & $184(5.9 \%)$ & $3128(100.0 \%)$ \\
\hline Total & $F \& \%$ & $3502(36.8 \%)$ & $3940(41.5 \%)$ & $1422(15.0 \%)$ & $641(6.7 \%)$ & $9505(100.0 \%)$ \\
\hline
\end{tabular}

Contingency Coefficient $=.053 ; \mathrm{P}=.000(\mathrm{HS})$

Table 11. Prevalence of openbite

\begin{tabular}{|c|c|c|c|c|c|}
\hline \multirow{2}{*}{$\begin{array}{c}\text { SCHOOL } \\
\text { TYPE }\end{array}$} & & \multicolumn{3}{|c|}{ OPENBITE } & \multirow{2}{*}{ Total } \\
\hline & & Absent & $<2 \mathrm{~mm}$ & $>4 \mathrm{~mm}$ & \\
\hline Government & $\mathrm{F} \& \%$ & $3035(96.7 \%)$ & $54(1.7 \%)$ & $50(1.6 \%)$ & $3139(100.0 \%)$ \\
\hline Aided & $F \& \%$ & $3152(97.3 \%)$ & $45(1.4 \%)$ & $41(1.3 \%)$ & $3238(100.0 \%)$ \\
\hline Private & $\mathrm{F} \& \%$ & $3027(96.8 \%)$ & $51(1.6 \%)$ & $50(1.6 \%)$ & $3128(100.0 \%)$ \\
\hline Total & $F \& \%$ & $9214(96.9 \%)$ & $150(1.6 \%)$ & $141(1.5 \%)$ & $9505(100.0 \%)$ \\
\hline
\end{tabular}

Contingency Coefficient $=.017 ; \mathrm{P}=.586$

Table 12. Prevalence of skeletal deviation in maxilla

\begin{tabular}{|c|c|c|c|c|c|}
\hline \multirow{2}{*}{$\begin{array}{c}\text { SCHOOL } \\
\text { TYPE }\end{array}$} & & \multicolumn{3}{|c|}{ MAXILLA } & Retrognathic \\
\cline { 3 - 5 } & & Normal & Prognathic & $52(1.7 \%)$ & $3139(100.0 \%)$ \\
\hline Government & F\&\% & $2889(92.0 \%)$ & $198(6.3 \%)$ & $29(.9 \%)$ & $3238(100.0 \%)$ \\
\hline Aided & F\&\% & $3055(94.3 \%)$ & $154(4.8 \%)$ & $46(1.5 \%)$ & $3128(100.0 \%)$ \\
\hline Private & F\&\% & $2961(94.7 \%)$ & $121(3.9 \%)$ & $127(1.3 \%)$ & $9505(100.0 \%)$ \\
\hline Total & F\&\% & $8905(93.7 \%)$ & $473(5.0 \%)$ & & 2 \\
\hline
\end{tabular}

Contingency Coefficient $=.054 ; \mathrm{P}=.000$

Table 13. Prevalence of skeletal deviation in mandible

\begin{tabular}{|c|c|c|c|c|c|}
\hline \multirow{2}{*}{$\begin{array}{l}\text { SCHOOL } \\
\text { TYPE }\end{array}$} & & \multicolumn{3}{|c|}{ MANDIBLE } & \multirow{2}{*}{ Total } \\
\hline & & Normal & Prognathic & Retrognathic & \\
\hline Government & $F \& \%$ & $1423(45.3 \%)$ & $29(.9 \%)$ & $1687(53.7 \%)$ & $3139(100.0 \%)$ \\
\hline Aided & $F \& \%$ & $1540(47.6 \%)$ & $17(.5 \%)$ & $1681(51.9 \%)$ & $3238(100.0 \%)$ \\
\hline Private & $F \& \%$ & $1433(45.8 \%)$ & $18(.6 \%)$ & $1677(53.6 \%)$ & $3128(100.0 \%)$ \\
\hline Total & $\mathrm{F} \& \%$ & $4396(46.2 \%)$ & $64(.7 \%)$ & $5045(53.1 \%)$ & $9505(100.0 \%)$ \\
\hline
\end{tabular}

Contingency Coefficient $=.028 ; \mathrm{P}=.108$ 
Table 14. Prevalence of oral habits

\begin{tabular}{|c|c|c|c|c|c|c|c|c|}
\hline \multirow{2}{*}{$\begin{array}{l}\text { SCHOOL } \\
\text { TYPE }\end{array}$} & & \multicolumn{6}{|c|}{ HABITS } & \multirow[b]{2}{*}{ Total } \\
\hline & & Absent & $\begin{array}{c}\text { Thumb } \\
\text { sucking }\end{array}$ & $\begin{array}{c}\text { Tongue } \\
\text { thrusting }\end{array}$ & $\begin{array}{c}\text { Lip } \\
\text { biting }\end{array}$ & $\begin{array}{c}\text { Nail } \\
\text { biting }\end{array}$ & $\begin{array}{c}\text { Mouth } \\
\text { breathing }\end{array}$ & \\
\hline Government & $\mathrm{F} \& \%$ & 2949(93.9\%) & $6(.2 \%)$ & $114(3.6 \%)$ & $8(.3 \%)$ & $10(.3 \%)$ & $52(1.7 \%)$ & $3139(100.0 \%)$ \\
\hline Aided & $F \& \%$ & 3054(94.3\%) & $3(.1 \%)$ & $114(3.5 \%)$ & $3(.1 \%)$ & $13(.4 \%)$ & $51(1.6 \%)$ & $3238(100.0 \%)$ \\
\hline Private & $F \& \%$ & 2983(95.4\%) & $7(.2 \%)$ & $97(3.1 \%)$ & $4(.1 \%)$ & $13(.4 \%)$ & $24(.8 \%)$ & $3128(100.0 \%)$ \\
\hline Total & $F \& \%$ & $8986(94.5 \%)$ & $16(.2 \%)$ & $325(3.4 \%)$ & $15(.2 \%)$ & $36(.4 \%)$ & $127(1.3 \%)$ & $9505(100.0 \%)$ \\
\hline
\end{tabular}

Contingency Coefficient $=.044 ; \mathrm{P}=.050$

\section{Discussion}

Karnataka is one of the major states of South India. Karnataka is the nine largest states in India in terms of Population. Cultural or geographic origin can also influence demand for treatment as stated by Mandall et al; Linder-Aronson et al [9]; Ngom et al [10] and Josefsson et al [11]. The impact of malocclusion is primarily psycho-social; hence knowledge on how individuals perceive and react to malocclusion in a community is necessary for effective orthodontic treatment and care. Study of the prevalence and pattern of distribution of malocclusion had been included in National Health surveys to derive valuable information to plan and develop the manpower and treatment facilities in Orthodontic specialty in many countries $[12,13,14]$ Although many studies have been reported on prevalence of malocclusion in different populations the review of literature showed that only few studies evaluated malocclusions in the referred population so as to plan and develop the treatment facilities based upon the pattern of the malocclusion and their frequencies of occurrences [15,16,17]. Ackermann- Proffit classification of malocclusion overcomes the major weaknesses of the Angle system. All three planes of space i.e, sagittal, transverse and vertical planes are taken into consideration. The differentiation between dental and skeletal problems is made at the appropriate level and diagnosis is inherent in this classification. An additional advantage is that the logical approach used in constructing the classification is similar to that employed for preparing computer programs. Hence this system lends itself well to surveys, where data processing by computers is desired. We have further modified this classification to include the oral habits as shown in the chart.

In our survey, we have observed the discrepancies in midline[Table1], spacing [Table2], crowding [Table3], protrusion and retrusion of teeth [Table $4 \& 5$ respectively] to be almost equally distributed in all 3 categories of school. Transverse deviation like cross-bite[Table7], was almost the same. Anteroposterior deviations like profile [Table6] and molar relation [Table8] were observed to be distributed equally in the schools. Overjet [Table9], overbite [Table10] and openbite [Table11] depicting the vertical deviations were similar. Finally the skeletal deviation of maxilla [Table12], mandible [Table13] and the the presence of oral habits [Table14] also did not show much of variation in the percentage distribution among the categories of schools. It was also thought earlier that the prevalence of malocclusion was more in school children of Government schools than when compared to the children in Private schools. This was attributed to the concept of lower awareness levels of children in Government schools than those in Private and Aided schools. This difference was mainly due to the lower socio-economic backgrounds of children of Government schools as identified by Wright [18], Chen [19] and Hamilton [20] which was hindering them from getting the necessary treatment. But the trend has changed now which might be due to the increase in the literacy rate. In our study the malocclusion prevalence is almost equally distributed in children of Government, Aided and Private schools. The state of Karnataka has witnessed a steady increase in the literacy rate which ranks $17^{\text {th }}$ in India. It has gone up from $66.64 \%$ to $75.60 \%$ i.e. a $9 \%$ increase in the last decade. Also the life styles of the people have changed with raise in the socio-economic conditions of the people with the better job opportunities which leads them to get the basic necessities for them. The children are getting enough exposure through media.

\section{Conclusion}

From the results of our survey, we concluded that the prevalence of malocclusion is distributed almost equally in children of Government, Aided and Private schools. Through this survey, we have recorded the prevalence of malocclusion of the children regarding the orthodontic treatment. Our primary concern was to educate the children as they are considered to be an important target group to provide proper guidance for maintaining oral health. These educated children can in turn take home the message about oral health, mal-alignment of teeth, consequences of the malocclusion and their treatment.

\section{REFERENCES}

[1] Dhar V, Jain A, Van Dyke T E, Kohli A 2007 Prevalence of gingival diseases, malocclusion and fluorosis in school-going children of rural areas in Udaipur district . Journal of the Indian Society of Pedodontics and Preventive 
Dentistry 25:103-105.

[2] Kenealy P, Frude N, Shaw W An evaluation of the psychological and social effects of malocclusion: some implications for dental policy making. Social Science \& Medicine 1989; 28: 583 - 591.

[3] Proffi t W R, Fields H W 2000 Contemporary orthodontics. 3rd edn Mosby, Inc, St Louis

[4] Grimm S , Frazao P , Antunes J L , Castellanos R A, Narvai P C 2004 Dental injury among Brazilian schoolchildren in the state of São Paulo . Dental Traumatology 20: 134 - 138.

[5] Greiger A 2001 Malocclusion as an etiologic factor in periodontal disease: a retrospective essay. American Journal of Orthodontics and Dentofacial Orthopedics 120: 112 115 .

[6] Lawrence E van kirk, Elliot HP. Assessment of malocclusion in population groups. American Journal of public Health 1959; 49(9):1157-1163.

[7] Chen MS, Hunter P. Oral health and quality of life in New Zealand: a social perspective. Soc Sci Med 1996; 43: 1213-22.

[8] James L. Ackerman and William R. Proffit. The characteristics of malocclusion: A modern approach to classification and diagnosis. Am J Orthod 1969; 56: 5, 443454

[9] Linder-Aronson S, Bjerrehorn K , Forsberg C-M. Objective and subjective need for orthodontic treatment in Stockholm Country. Swedish Dental Journal 2002; 26: 31 40

[10] Ngom P I, Brown R, Diagne F, Normand F, Richmond S. A cultural comparison of treatment need. European Journal of Orthodontics 2005; 27: $597-600$
[11] Josefsson E, Bjerklin K, Lindsten R 2007 Malocclusion frequency in Swedish and immigrant adolescents influence of origin on orthodontic treatment need. European Journal of Orthodontics 29: $79-87$

[12] Eagly AH, Ashmore RD, Makhijani MG, Longo LC. What is beautiful is good, but. A meta-analytic review of research on the physical attractiveness stereotype. Psychological Bulletin 1991; 110: 109-128

[13] Feingold A. Good-looking people are not what we think. Psychological Bulletin 1992; 111: 304-341.

[14] Taylor SE, Peplau LA, Sears DO. Social Psychology. Prentice hall, New Jersey 2000.

[15] Jones WB. Malocclusion and facial types in a group of Saudi Arabian patients referred for orthodontic treatment: a preliminary study. Br J Orthod 1987; 14; 143-146.

[16] Sayin MO, Turkkahraman H. Malocclusion and crowding in an orthodontically referred Turkish population. Angle Orthodontist 2003; 74:635-639.

[17] Migale D, Barbato E, Bossù M, Ferro R, Ottolenghi L. Oral health and malocclusion in 10-11 years-old children in southern Italy. Eur J Paediatr Dent. 2009; 10(1):13-8.

[18] Wright FA. Children's perception of vulnerability to illness and dental disease. Community Dent Oral Epidemiology 1982; 10: 29-32.

[19] Chen MS. Children's preventive dental behavior in relation their mothers' socioeconomic status, health beliefs and dental behaviors. J DentChild1986; 53:105-9.

[20] Hamilton ME, Coulby WM. Oral health knowledge and habits of senior elementary school students. J Public Health Dent 1991; 51: 212-9. 